\title{
Study of Water Oxidation and Oxygen Reduction Reactions by Prussian blue and Analogues Compounds
}

\author{
Daniel Salomão Doretto*, Priscilla J. Zambiazi, Gabriel de O. Aparecido, Juliano Alves Bonacin.
}

\begin{abstract}
Electrocatalytic processes of water oxidation and oxygen reduction reactions are getting highlighted due to its importance in the development of electrochemical systems to convert and store energy. Oxygen reduction reaction (ORR) in acid and alkaline aqueous solutions demonstrate kinetics and thermodynamic complexity. In sight of that, electrocatalytic analysis of the $\mathrm{Fe}_{3}{ }_{3}\left[\mathrm{Fe}^{\prime \prime \prime}(\mathrm{CN})_{6}\right]_{2}$ (PB) and $\mathrm{Co}_{3}{ }_{3}\left[\mathrm{Fe}^{\mathrm{III/1}}(\mathrm{CN})_{6}\right]_{2}$ (Co-PBA) thin films (prepared by electrodeposition) for water oxidation reaction (WOR) and oxygen reduction reaction (ORR) were evaluated in acid aqueous solution and in $\mathrm{KCl}(0.1 \mathrm{M})$ and $\mathrm{KNO}_{3}(0.5 \mathrm{M})$ electrolytes. The PBAs catalysts thin films are highly stable and capable of keeping its catalytic activities during several cycles.
\end{abstract}

\section{Keywords:}

Oxygen reduction reaction (ORR), water oxidation reaction (WOR), Prussian blue and its analogues.

\section{Introduction}

Water splitting is one of the methods for hydrogen gas generation. In this process the anode produce oxygen through oxygen evolution reaction (OER), the cathode produce hydrogen through hydrogen evolution reaction (HER). These are examples of feasible electrochemical reactions by the use of electroactive catalyst. In this way many studies for the prussian blue analogues (PBAs) modified electrodes electrocatalyst activity has been contrasting. Prussian blue isostructural compounds $\left(\mathrm{Fe}_{3}{ }_{3}\left[\mathrm{Fe}^{\mathrm{III}}(\mathrm{CN})_{6}\right]_{2} \quad\right.$ (PB) and $\mathrm{Co}_{3}{ }_{3}\left[\mathrm{Fe}^{\mathrm{IIII \prime \prime}}(\mathrm{CN})_{6}\right]_{2}$ (Co-PBA)) have been prepared and theirs electrocatalytic properties analyzed by cyclic and linear voltammetry in $\mathrm{KCl}(0.1 \mathrm{M})$ and $\mathrm{KNO}_{3}(0.5 \mathrm{M})$ electrolytes respectively.

\section{Results and Discussion}

The electrodes modified electrochemically were obtained from the metallic salt $\mathrm{K}_{3}\left[\mathrm{Fe}^{\prime \prime \prime}(\mathrm{CN})_{6}\right]$ and $\mathrm{K}_{4}\left[\mathrm{Fe}^{\prime \prime}(\mathrm{CN})_{6}\right], \mathrm{Fe}^{2+}$ and $\mathrm{Co}^{2+}$, forming the prussian blue $\mathrm{Fe}_{3}{ }_{3}\left[\mathrm{Fe}^{\prime \prime \prime}(\mathrm{CN})_{6}\right](\mathrm{PB})$ and its cobalt analogues $\mathrm{K}_{2} \mathrm{Co}_{3}{ }_{3}\left[\mathrm{Fe}{ }^{\prime \prime}(\mathrm{CN})_{6}\right]_{2}$ (Co-Fe"PBA) and $\mathrm{Co}_{3}{ }_{3}\left[\mathrm{Fe}^{\mathrm{II}}(\mathrm{CN})_{6}\right]_{2}$ (Co-Fe'"IBA). The PB thin film was obtained through its deposition on the FTO work electrode by cyclic voltammetry between the potentials -0.245 to $0.555 \mathrm{~V}$, with a scan rate of $10 \mathrm{mVs}^{-1}$, in a free oxygen electrolytic cell containing $10 \mathrm{mM} \mathrm{FeCl}$, $\mathrm{K}_{3}\left[\mathrm{Fe}^{\prime \prime \prime}(\mathrm{CN})_{6}\right]$ and $0,1 \mathrm{M} \mathrm{KCl} / \mathrm{HCl}$. For the Co-Fe ${ }^{1 / / 1 / 1} \mathrm{PBA}$ films firstly was deposited a $\mathrm{Co}^{\circ}$ metallic film from a solution of $0,1 \mathrm{M} \mathrm{CoSO}_{4} \mathrm{pH} 3$ by chronoamperometry applying a potential of $-1.6 \mathrm{~V}$ over $60 \mathrm{~s}$, then the modified electrode with $\mathrm{Co}^{\circ}$ metallic film were treated with solutions of $\mathrm{K}_{3}\left[\mathrm{Fe}^{\prime \prime \prime}(\mathrm{CN})_{6}\right]$ and $\mathrm{K}_{4}\left[\mathrm{Fe}^{\prime \prime}(\mathrm{CN})_{6}\right]$, through a potential of $0.5 \mathrm{~V}$ for $300 \mathrm{~s}$ forming thin films of Co-Fe"PBA and Co-Fe"l'PBA respectively.

Electrocatalytic analysis were taken from the modified electrodes in $\mathrm{O}_{2}$ solutions for oxygen reduction reaction (ORR) and in absence of $\mathrm{O}_{2}$ for water oxidation reaction (WOR). The prussian blue $\mathrm{Fe}^{\mathrm{II}} \mathrm{Fe}$ "II analysis performed in a $0.1 \mathrm{M} \mathrm{KCl}$ solution. For Co-PBA Co"Fe"l' and Co"Fe" the electrocatalytic analysis were taken in $0.5 \mathrm{M} \mathrm{KNO}_{3}$ solution.
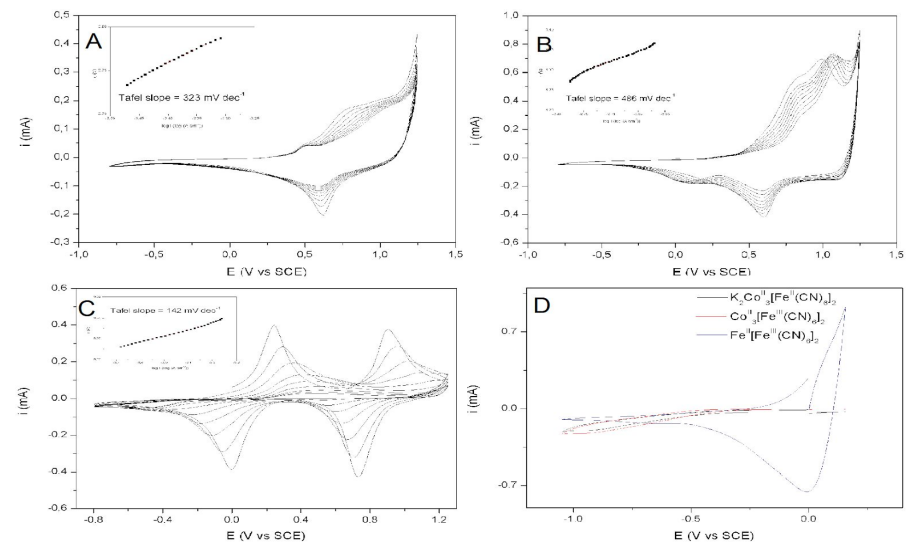

Figura 1. WOR electrocatalytic activities of $A$ ) Co-Fe"'IPBA, B) Co-Fe"PBA and C) PB and D) RRO of Co-Fe ${ }^{I / / I I} P B A$ and $P B$.

\section{Conclusions}

After the prussian blue and analogues electrocatalytic analysis can highlight the PB $\left(\mathrm{Fe}_{3}{ }_{3}\left[\mathrm{Fe}^{\prime \prime \prime}(\mathrm{CN})_{6}\right]_{2}\right)$ result as it is the catalyst with the lowest degradation among those studied in WOR, also the one with the best yield, presenting a tafel slope value of $142 \mathrm{mV} \mathrm{dec}^{-1}$. Furthermore this catalyst have obtained the lowest overpotential value for water oxidation compared to the others in this study.

\begin{tabular}{l}
\multicolumn{3}{c}{ Acknowledgement } \\
CNPq, Fapesp (grant\#2013/22127-2 e \\
grant\#2017/23960-0) e Capes.
\end{tabular}

\footnotetext{
Pires, B. M.; Galdino, F. E.; Bonacin, J. A. Electrocatalytic Reduction of Oxygen by Metal Coordination Polymers Produced from Pentacyanidoferrate(II) Complex. Inorganica Chimica Acta 2017, 466, 166-173.

2 Aksoy, M.; Nune, S. V. K.; Karadas, F. A Novel Synthetic Route for the Preparation of an Amorphous Co/Fe Prussian Blue Coordination Compound with High Electrocatalytic Water Oxidation Activity. Inorg. Chem. 2016, 55 (9), 4301-4307.

Han, L.; Tang, P.; Reyes-Carmona, Á.; Rodríguez-García, B.; Torréns, M.; Morante, J. R.; Arbiol, J.; Galan-Mascaros, J. R. Enhanced Activity and Acid PH Stability of Prussian Blue-Type Oxygen Evolution Electrocatalysts Processed by Chemical Etching. J. Am. Chem. Soc. 2016, 138 (49), 16037-16045.
} 